\title{
UTJECAJ RAZLIČITIH OBLIKA ZRNA PŠENICE NA HEKTOLITARSKU MASU
}

\author{
INFLUENCE OF DIFFERENT WHEAT GRAIN SHAPES \\ ON TEST WEIGHT
}

\section{Ž. Jukić, Tajana Krička, Ana Pospišil, T. Radiček, Karmen Jukić}

\section{SAŽETAK}

Hektolitarska masa je parametar kakvoće pšenice na čiju vrijednost utječe više čimbenika. Cilj ovog istraživanja bio je utvrditi razlike u nekim fizikalnim svojstvima pšenice kada se zrna razlikuju prema debljini, a istraživanje je provedeno u tvrtki Belje d.d. Mlinarstvo Križevci u 2012. godini. Za potrebe istraživanja, uzorci zrna ručno su uzeti tijekom transportiranja zrna iz skladišnog prostora u mlinsku čistionicu i neposredno prije početka mljevenja zrna (prije 1. krupljenja). Prosijavanjem zrna na sitima, dobivene su četiri frakcije zrna prema debljini (F1 > od 3,0 mm; F2 > od 2,5 mm; F3 > od $2,25 \mathrm{~mm}$ i F4 $>$ od 2,0mm). Najviše zrna u postotku utvrđeno je u F2 (debljina zrna $>2,5 \mathrm{~mm}$ ) kako u uzorcima koji su uzeti prije mlinske čistionice $(60,82 \%)$ tako i u uzorcima koji su uzeti prije 1. krupljenja (62,93\%). Hektolitarska i masa 1000 zrna smanjuju se sa smanjenjem debljine zrna tj., od F1 prema F4. Statistička analiza varijance pokazala je značajne razlike u hektolitarskoj i masi 1000 zrna između frakcija zrna. Iako je prosječna masa 1000 zrna bila veća u $\mathrm{F} 1$, u odnosu na F2, razlike u hektolitarskoj masi između F1 i F2 bile su neznatne, kako u uzorcima koji su uzeti prije mlinske čistionice tako i u uzorcima koji su uzeti prije 1. krupljenja. Iako u ovom istraživanju nije određen prinos brašna u frakcijama zrna, na osnovi dosadašnjih znanstvenih spoznaja mogu se očekivati bolji rezultati u preradi u frakcijama 1 i 2 u odnosu na frakcije 3 i 4.

Ključne riječi: debljina zrna, frakcije zrna, hektolitarska masa, pšenica

\begin{abstract}
The test weight is a parameter of wheat quality whose value is influenced by several factors. The aim of this research was to determine the differences in some grain physical properties of wheat when the grains differ in thickness. The research was conducted in the year 2012, at the company Belje d.d. Mlinarstvo Križevci. For research purposes, grain samples were taken by hand during the
\end{abstract}


transport of grain from the storage to the mill and immediately before grain milling (before the $1^{\text {st }}$ break). By sieving the grain on sieves, four grain fractions were obtained according to thickness (F1> of $3.0 \mathrm{~mm}$; F2 $>$ of $2.5 \mathrm{~mm}$; $\mathrm{F} 3>$ of $2.25 \mathrm{~mm}$ and F4> of $2.0 \mathrm{~mm}$ ). The highest percentage of grain was found in F2 (grain thickness $>2.5 \mathrm{~mm}$ ) both in samples taken before the cleaninghouse $(60.82 \%)$ and in samples taken before $1^{\text {st }}$ break $(62.93 \%)$. Test weight and 1000 grain weight decrease with decreasing grain thickness, ie, from F1 to F4. Statistical analysis of variance showed significant differences in test weight and 1000 grain weight between grain fractions. Although the average weight of 1000 grains was higher in F1, compared to F2, the differences in test weight between F1 and F2 were insignificant, both in the samples taken before the cleaninghouse and in the samples taken before the $1^{\text {st }}$ break. In this research, flour yield in grain fractions was not determined, but on the basis of previous scientific knowledge, better grinding results can be expected in fractions 1 and 2 compared to fractions 3 and 4 .

Key words: grain thickness, grain fractions, test weight, wheat

\section{UVOD}

Hektolitarska masa ili masa po jedinici volumena, jedno je od najstarijih i najviše korištenih mjerila kakvoće u trgovini pšenicom (Zeleny, 1971.; Pushman i Bingham, 1975., cit. Czarnecki i Evans, 1986.). Hektolitarska masa je parametar kakvoće pšenice na čiju vrijednost utječe više čimbenika. Pregledom dostupne literature utvrđeno je da na hektolitarsku masu utječu svojstva genotipa pšenice (Altaf Ali i sur., 1969., Kljusurić, 2000., Pospišil, 2010., Boz i sur., 2012., PonceGarcía i sur., 2017.), klimatske prilike (Havlerson i Zeleny, 1988., Milner i Shellenberger, 1983., cit. Czarnecki i Evans, 1986., Bracken i Bailey, 1928., cit. Czarnecki i Evans, 1986) i agrotehnički zahvati tijekom uzgoja pšenice (Varga i sur., 2000., 2003.; Protić i sur., 2007). Vegetacijska godina, sorta i njihova interakcija značajno utječu, kako na masu 1000 zrna, tako i na hektolitarsku masu, navode Varga i sur. (2000). Na vrijednost hektolitarske mase utječu vlaga zrna i prisutnost različitih primjesa u masi zrna iz koje se određuje hektolitarska masa (Vešnik i sur., 1989., Krička i sur., 1997.). Također, na vrijednost hektolitarske mase utječe i način postupanja s hektolitarskom ili Schopper-ovom vagom prilikom obavljanja analize (Ujević, 1988.). Prilikom određivanja, na vrijednost hektolitarske mase suhe i očišćene pšenice utječu oblik, jednolikosti i gustoća zrna te učinkovitost pakiranja zrna u mjernoj posudi (Halverson i Zeleny, 1988.). Yamazaki i Briggle (1969.) te Schuler i sur. (1995.) iznose podatke o nesignifikantnoj korelaciji između hektolitarske mase i dužine, širine, mase i volumena zrna. Altaf Ali i Atkins (1969.), pronašli su, da 
su gustoća zrna, širina i debljina bili u korelaciji s hektolitarskom masom. Yamazaki i Briggle (1969.) koriste izraz učinkovitost pakiranja zrna (engl. packing efficiency) umjesto izraza kakvoća pakiranja zrna (engl. packing quality) koje je koristio Roberts (1910.). Autori su pronašli visoku korelaciju između učinkovitosti pakiranja zrna u posudi i hektolitarske mase ali nisu dobili značajnu korelaciju između gustoće i hektolitarske mase. Ghaderi i sur. (1971.) navode sljedeće: učinkovitost pakiranja zrna u posudi pod utjecajem je oblika zrna i svojstava perikarpa. Korelacija između širine zrna i volumena bila je visoko signifikantna. Korelacija između mase zrna i širine također je bila visoko signifikantna ali korelacija između mase zrna i dužine zrna nije bila signifikantna. Autori pretpostavljaju da je širina zrna više pod utjecajem okoline nego dužina zrna. Geometrijska svojstva, kao što su veličina i oblik, jedna su od najvažnijih fizikalnih svojstava koja se razmatraju tijekom prerade žitarica. Oblik pšenice može se opisati kao okrugli (sličan kugli - sferoidu). Zrno pšenice ima tri glavne dimenzije i to su: dužina, širina i debljina (Ponce-García i sur., 2017.). Za proizvođače brašna tj. mlinare jednolikost zrna potencijalno je važno fizičko svojstvo. U procesu mljevenja, kondicionirana pšenica prvo se melje na nekoliko krupača kako bi se odvojio endosperm od vanjskog omotača (perikarp). U slučaju kada je velika varijacija u veličini zrna, mala zrna prolaze kroz krupače nedovoljno samljevena ili polomljena $\mathrm{u}$ početnom procesu krupljenja. To zahtijeva dodatan postupak s ovakvim zrnom. Dodatni postupak zahtijeva više vremena za mljevenje i povećava potrošnju energije. Osim toga, dodatna prerada može smanjiti kakvoću brašna. Kada su zrna pšenice jednoličnija, može se očekivati i veće izbrašnjavanje (Yoon i sur., 2002.).

Cilj ovog istraživanja bio je utvrditi razlike u nekim fizikalnim svojstvima pšenice kada se zrna razlikuju prema debljini.

\section{MATERIJAL I METODE ISTRAŽIVANJA}

Istraživanja o utjecaju različitih debljina zrna pšenice na vrijednosti nekih fizikalnih svojstava, napravljena su u tvrtki Belje d.d. Mlinarstvo, Križevci u 2012. godini. Za potrebe istraživanja, uzorci zrna ručno su uzeti tijekom transportiranja zrna iz skladišnog prostora $u$ mlinsku čistionicu i neposredno prije početka mljevenja zrna (prije 1. krupljenja). Masa uzoraka približno je iznosila $5 \mathrm{~kg}$. Ovi uzorci prosijani su na sitima s ovalnim perforacijama $(1 \mathrm{~mm}$ x $25 \mathrm{~mm}, 2 \mathrm{~mm}$ x $25 \mathrm{~mm}$ i $3,5 \mathrm{~mm}$ x $25 \mathrm{~mm}$ ), kako bi se izdvojile sve primjese i nečistoće, te štura i polomljena zrna (Službeni list 74/88). Nakon izdvajanja primjesa, uzroci su promiješani i iz njih su postupkom četvrtanja, napravljeni prosječni uzorci čija je masa iznosila $500 \mathrm{~g}$. Iz tih uzoraka napravljene su 
sljedeće analize: hektolitarska i masa 1000 zrna, sadržaj vode u zrnu (\%), sadržaj proteina (\%) i sadržaj vlažnog lijepka (glutena, \%). Sadržaj vode u zrnu određen je pomoću laboratorijske sušnice i vlagomjera za zrno (DICKEY-john GAC 2100; DICKEY-john, Corporation, Illinois, USA). Sadržaj proteina i sadržaj vlažnog lijepka određeni su pomoću NIR - spektrofotometra (AgriCheck, Bruins Instruments, Salem, USA). Hektolitarska masa određena je pomoću Schopper-ove vage, a masa 1000 zrna, brojanjem i vaganjem 4 puta po 100 zrna. Prosječni uzorci od 500 g. smanjeni su postupkom četvrtanja na uzorke mase 200 g. Uzorci od 200 g. korišteni su u postupku prosijavanja u kojem je zrno propušteno kroz sustav sita, kako bi se odredio maseni i postotni udio svake frakcije zrna. Korištena su sita s ovalnim perforacijama, širine od 2,0 do $3,0 \mathrm{~mm}$, dužine 25 i $30 \mathrm{~mm}$. Svaka frakcija dobila je slovnu i brojčanu oznaku kako slijedi:

1. frakcija $(\mathrm{F} 1)=$ debljina zrna iznad $3,0 \mathrm{~mm}$

2. frakcija (F2) = debljina zrna iznad $2,5 \mathrm{~mm}$

3. frakcija (F3) = debljina zrna od iznad $2,25 \mathrm{~mm}$

4. frakcija $(\mathrm{F} 4)=$ debljina zrna iznad $2,0 \mathrm{~mm}$

Na svakom situ određena je masa zrna. Mase zrna na sitima su zbrojene i određen je postotni udjel svake frakcije zrna. Preostala količina zrna iz uzoraka koji su uzeti prije mlinske čistionice i iz uzoraka koji su uzeti prije 1.krupljenja, razdvojena je prosijavanjem kroz sita na četiri prije navedene frakcije, kako bi se mogle utvrditi razlike između frakcija. Iz svake frakcije zrna postupkom četvrtanja napravljeni su prosječni uzorci od 200 g. U ovim uzorcima određeni su hektolitarska i masa 1000 zrna, sadržaj vode u zrnu (\%) te sadržaj proteina (\%) i vlažnog lijepka (\%). Navedeni parametri analizirani su na istoj opremi koja je korištena i za analize zrna prije frakcioniranja (DICKEY-john GAC 2100, AgriCheck i Schopper-ova vaga). Vrijednosti svih prije navedenih analiziranih parametara, preračunate su na vrijednost vlage od $13 \%$, a nakon toga napravljena je statistička analiza varijance.

\section{REZULTATI I RASPRAVA}

Kakvoća mješavine pšenica prije mlinske čistionice i prije 1. krupljenja

Kada se usporede podaci iz tablice 1 , može se utvrditi da se sadržaj vode u zrnu povećao u uzorcima prije 1. krupljenja u odnosu na uzorke koji su uzeti prije mlinske čistionice, za 1,2\%. Razlog tome je što se tijekom pripreme pšenice za mljevenje dodaje voda kako bi se u procesu mljevenja lakše odvojio omotač ili perikarp od jezgre zrna. 
Mješavina pšenica imala je dobre parametre kakvoće (tablica 1). Utvrđena je razlika između uzoraka koji su uzeti prije mlinske čistionice i uzoraka koji su uzeti prije 1. krupljenja.

Hektolitarska i masa 1000 zrna te sadržaj proteina i sadržaj vlažnog lijepka, nešto su manji u uzrocima koji su uzeti prije 1. krupljenja. Prema vrijednostima za hektolitarsku masu može se očekivati dobar prinos brašna. Generalno, što je veća hektolitarska masa, to je i kvalitetnija pšenica odnosno i mješavina pšenica koja će ići u preradu. Sadržaj proteina bio je iznad 12\%. Prema podacima iz literature, minimalna vrijednost sadržaja proteina u zrnu pšenice iz koje se može dobiti kvalitetni kruh, iznosi 12\% (Jelača, 1972.). Istraživanjima je dokazano da se u kruhu sadržaj proteina smanji za 1 do $1,5 \%$ u odnosu na pšenicu iz koje je nastao. Prema podacima o vlažnom lijepku može se utvrditi da će se iz ovakve mješavine pšenica iz koje su uzeti uzorci, dobiti brašna sa srednjim sadržajem vlažnog lijepka. Naime, kako tvrdi Đaković (1980.), brašna su siromašna lijepkom ako ga sadržavaju manje od $23 \%$, srednji sadržaj lijepka imaju brašna koja ga sadrže između 23 i 30\%, dok su brašna bogata lijepkom ako ga sadržavaju više od $30 \%$. Masa 1000 zrna bila je u granicama kvalitetnih sorata pšenice $(28$ - 45 g. na suhu tvar, širi prosjek, Đaković, 1980). Razlike između uzoraka koji su uzeti prije mlinske čistionice i prije 1. krupljenja moguće je objasniti time da analize nisu rađene na istim uzorcima jer su uzorci uzimani tijekom određenog vremenskog razdoblja, tako da je tijekom prolaska mješavine pšenice kroz postrojenje mogla proći nešto kvalitetnija pa onda nešto manje kvalitetna pšenica.

Tablica 1. Parametri kakvoće mješavine pšenica u uzorcima koji su uzeti prije mlinske čistionice (pmč) i prije 1. krupljenja (ppk) (13\% vlage)

Table 1 Quality parameters of wheat mixture in samples taken before cleaninghouse (pmč) and before $1^{\text {st }}$ break (ppk) (13\% moisture)

\begin{tabular}{|c|c|c|c|c|c|c|c|c|c|}
\hline \multicolumn{2}{|c|}{$\begin{array}{l}\text { Hektolitarska } \\
\text { masa/ } \\
\text { Test weight } \\
(\mathrm{kg} / \mathrm{hl}) \\
\end{array}$} & \multicolumn{2}{|c|}{$\begin{array}{c}\text { Sadržaj } \\
\text { vode u zrnu/ } \\
\text { Moisture content } \\
(\%) \\
\end{array}$} & \multicolumn{2}{|c|}{$\begin{array}{c}\text { Sadržaj } \\
\text { proteina/ } \\
\text { Protein content } \\
(\%) \\
\end{array}$} & \multicolumn{2}{|c|}{$\begin{array}{l}\text { Sadržaj vlažnog } \\
\text { lijepka/ } \\
\text { Wet gluten content } \\
(\%)\end{array}$} & \multicolumn{2}{|c|}{$\begin{array}{c}\text { Masa } \\
1000 \text { zrna/ } \\
1000 \text { grain weight } \\
\text { (g.) }\end{array}$} \\
\hline pmč & ppk & pmč & ppk & pmč & ppk & pmč & ppk & pmč & ppk \\
\hline $81,78 \dagger$ & 79,50 & 12,58 & 13,78 & 12,58 & 12,32 & 25,28 & 23,42 & 36,60 & 36,40 \\
\hline $0,46 \neq$ & 0,49 & 0,37 & 0,43 & 0,08 & 0,08 & 0,53 & 1,08 & 2,30 & 3,21 \\
\hline $0,56 \#$ & 0,62 & 2,94 & 3,14 & 0,67 & 0,68 & 2,08 & 4,59 & 6,29 & 8,82 \\
\hline
\end{tabular}

$\dagger$ - prosjek/average; $\$$ - standardna devijacija/standard deviation; \# - koeficijent varijacije/coefficient of variation (\%); (isti je redoslijedu svakom stupcu/the same order is in each column) 
Distribucija vrijednosti debljine zrna $u$ uzorcima prije mlinske čistionice i prije 1. krupljenja

Kao što je vidljivo iz slike 1, utvrđena je razlika između frakcija u uzorcima koji su uzeti prije mlinske čistionice i u uzorcima koji su uzeti prije prvog krupljenja. Utvrđeno je da najviše zrna u prosjeku ima u frakcijama 2 i 3, s tim da je više zrna utvrđeno u prosjeku u frakciji 2 u uzorcima prije prvog krupljenja, a u frakciji 3 u uzorcima prije mlinske čistionice.

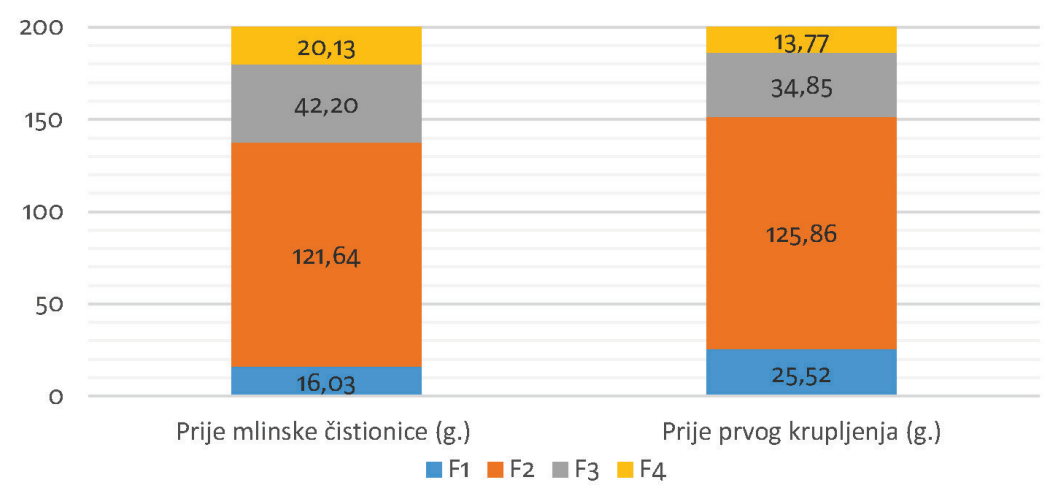

Slika 1. Prosječna masa zrna u frakcijama zrna

Figure 1 Average grain weight in grain fractions

Tijekom pripreme zrna za mljevenje došlo je do promjene u masenom i postotnom udjelu svih frakcija, s tim da je u uzorcima prije 1. krupljenja, smanjen udjel najsitnijih zrna i povećan udjel najkrupnijih zrna (slike 1 i 2).

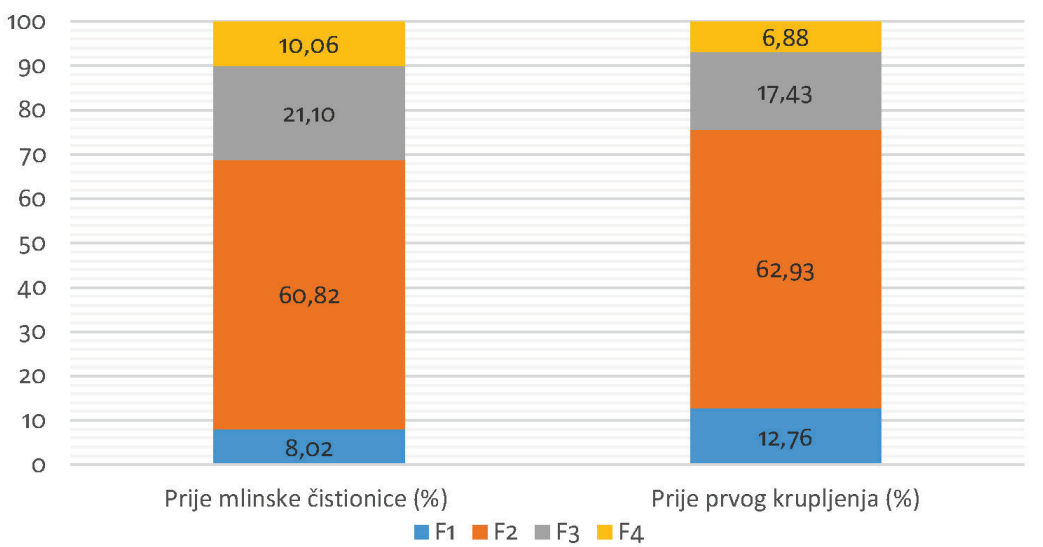

Slika 2. Postotni udjel frakcija zrna

Figure 2 Percentage proportion of the grain fractions 
Na osnovi vrijednosti koeficijenta varijacije $(\mathrm{CV}, \%)$ može se utvrditi da su dobivene vrijednosti najmanje varirale $u$ frakciji $2(3,55 \%)$, a najviše $u$ frakciji 1 $(15,28 \%)$, dok su u frakcijama 3 i 4 dobivene vrijednosti približno jednako varirale $(10,80 \%$ i $11,03 \%)$. Navedeno se odnosi na uzorke koji su uzeti prije mlinske čistionice.

U uzorcima koji su uzeti prije prvog krupljenja, unutar frakcija najmanje variranje utvrđeno je u frakciji 2 (2,04\%), a najveće u frakciji $4(20,33 \%)$. Unutar frakcije 1 variranje (18,44\%) bilo je veće nego variranje unutar frakcije 3 (4,99\%). Dakle, može se utvrditi da je između uzoraka koji su uzeti prije mlinske čistionice i onih koji su uzeti prije prvog krupljenja, bilo razlike u distribuciji veličine zrna. Variranje unutar frakcije 2 bilo je najmanje kako u uzorcima koji su uzeti prije mlinske čistionice, tako i u uzorcima koji su uzeti prije prvog krupljenja, s tim da je u frakciji 2 utvrđeno i najviše zrna.

Parametri kakvoće zrna u frakcijama prije mlinske čistionice i prije 1. krupljenja

$\mathrm{U}$ tablici 2. prikazane su vrijednosti hektolitarske mase i mase $1000 \mathrm{zrna} u$ frakcijama zrna prije mlinske čistionice i prije 1. krupljenja. Hektolitarska masa smanjuje se kako se smanjuje i debljina zrna. Provedena analiza varijance pokazala je, da se hektolitarska masa značajno razlikovala između frakcija. Slično su utvrdili i Ghaderi i sur. (1971.). Iako u ovom istraživanju nije napravljena korelacija između debljine zrna i hektolitarske mase, ipak je jasno vidljiv trend da se sa smanjenjem debljine zrna smanjuje i vrijednost hektolitarske mase. Dobiveni rezultati su u suglasju s navodima iz literature. Naime i Altaf Ali i Atkins (1969.) i Varga i sur. (2003.) utvrdili su pozitivnu korelaciju između debljine zrna i hektolitarske mase. Važno je navesti da prema vrijednostima hektolitarske mase, zrno u frakciji 4, još uvijek zadovoljava za primjenu u mlinsko-pekarskoj industriji, jer je prosječna vrijednost hektolitarske mase iznad $76 \mathrm{~kg} / \mathrm{hl}(78,18 \mathrm{i} 77,70 \mathrm{~kg} / \mathrm{hl}$, tablica 2). Vrijednost hektolitarske mase bila je manja u uzorcima prije 1 . krupljenja. To je zato jer se u masu zrna pšenice prije mljevenja dodaje voda kako bi se lakše odvojili omotač (perikarp) i klica od endosperma. Dodavanjem vode omotač (perikarp) se povećava (širi se) što uzrokuje povećanje veličine zrna ali se masa zrna ne povaćava slično kao i veličina što ima za posljedicu smanjenje vrijednosti hektolitarske mase. Slično objašnjenje dali su i Debbouz i sur. (1995) odnosno, autori su objasnili zašto se smanjuje hektolitarska masa pšenice kada prevladava kišno i vlažno vrijeme u polju prije žetve. 
Smanjenje vrijednosti mase 1000 zrna u uzorcima prije 1 . krupljenja, nastalo je zbog postupka pripreme zrna prije mljevenja gdje se zrno u mlinskoj čistionici površinski obrađuje i uklanja dio omotača (perikarpa), kako bi se na površini zrna našlo što manje nečistoća i mikroorganizama i smanjio udjel pepela (Kljusurić, 2000.). Masa 1000 zrna, slično kao i hektolitarska masa, smanjuje se od frakcije 1 prema frakciji 4 (tablica 2). Masa 1000 zrna u frakciji 1, u prosjeku, i više je nego dvostruko veća od iste u frakciji 4. Navedeno vrijedi kako u uzorcima koji su uzeti prije mlinske čistionice tako i u uzorcima koji su uzeti prije mlinske čistionice. Nakon provedene analize varijance utvrđeno je, da je masa 1000 zrna, bila značajno različita između frakcija (tablica 2). Acar i sur. (2019.) proveli su istraživanje na tri krušne sorte pšenice kako bi između ostalog utvrdili i utjecaj veličine zrna na svojstva zrna. Zrno sorata koje su korištene u istraživanju, podijeljeno je prema veličini u tri skupine. Autori navode, da je došlo do smanjenja mase 1000 zrna kako se smanjuje veličina zrna, što je prema autorima i bilo za očekivati. Kod dva kultivara sa smanjenjem veličine zrna značajno se smanjio sadržaj proteina i vlažnog lijepka, dok kod jednog kultivara nije utvrđeno smanjene navedenih parametara sa smanjenjem veličine zrna. Razdvajanjem uzoraka zrna prema debljini zrna, može se točnije utvrditi povezanost između mase 1000 zrna i hektolitarske mase.

Tablica 2. Prosječne vrijednosti hektolitarske mase i mase 1000 zrna u frakcijama zrna

Table 2 Average values of test weight and 1000 grain weight in grain fractions

\begin{tabular}{|c|c|c|c|c|c|c|}
\hline \multirow{2}{*}{ Parametar kakvoće/Quality parameters } & \multicolumn{5}{|c|}{ Frakcija/Fraction } \\
\cline { 3 - 7 } \multicolumn{2}{|c|}{} & F1 & F2 & F3 & F4 & LSD (0,05) \\
\hline $\begin{array}{c}\text { Hektolitarska masa/ } \\
\text { Test weight (kg/hl) }\end{array}$ & pmč & 81,75 & 81,79 & 80,27 & 78,18 & 0,54 \\
\cline { 2 - 7 } & ppk & 80,57 & 80,43 & 79,26 & 77,70 & 0,56 \\
\hline $\begin{array}{c}\text { Masa } 1000 \mathrm{zrna} / \\
1000 \text { grain weight (g.) }\end{array}$ & pmč & 49,37 & 38,92 & 30,65 & 24,63 & 0,72 \\
\cline { 2 - 7 } & ppk & 48,31 & 38,61 & 29,65 & 23,95 & 0,86 \\
\hline
\end{tabular}

pmč - prije mlinske čistionice/before cleaninghouse; ppk - prije prvog krupljenja/before 1st break $\operatorname{LSD}(0,05)$ za usporedbu između frakcija/ for comparison between fractions

Razlika između frakcija zrna u prosječnom sadržaju vode u zrnu nije bila velika (tablica 3). U uzorcima koji su uzeti prije prvog krupljenja, prosječni sadržaj vode u zrnu povećavao se od frakcije 1 prema frakciji 4, što nije bio slučaj u uzorcima koji su uzeti prije mlinske čistionice. Razlika u sadržaju vode između zrna iz frakcija kako u uzorcima prije mlinske čistionice tako i u uzorcima prije 1. krupljenja može biti iz razloga što se zrna razlikuju po strukturi zrna tj., zrna se mogu razlikovati u odnosu brašnavog i staklavog endosperma. Naime, dokazano je da se povećanjem sadržaja proteina u zrnu, povećava staklavost pa i tvrdoća zrna. Brašnava i staklava zrna ne upijaju vodu 
jednako (Dziki i Laskowski, 2005.). Proces kondicioniranja pšenice obuhvaća dodavanje vode u masu zrna pšenice i odležavanje tijekom kojeg zrna moraju upiti određenu količinu dodane vode. Čimbenici koji utječu na sadržaj vode koju će upiti zrno pšenice tijekom kondicioniranja su: temperatura zraka u prostoru u kojem se dodaje voda $\mathrm{i} u$ kojem se nalazi pšenica tijekom odležavanja, količina dodane vode, duljina odležavanja, genotip (struktura zrna), veličina zrna i temperatura zrna te sadržaj vode u zrnu prije kondicioniranja (Posner i Hibbs, 1997.). Razlike između frakcija u sadržaju vode u zrnima može se objasniti i time što voda ne prodire istom brzinom u mala, srednja i velika zrna što navode Li i Posner (1987.), a citira ih Posner (2000.). Sadržaj vode u zrnima u uzorcima koji su uzeti prije 1. krupljenja, bio je u prosjeku manji u svim frakcijama nego što bi trebao biti (tijekom kondicioniranja, sadržaj vode u zrnima je od 14,0 do $15 \%$ i više postotaka ovisno o tomu da li ima više brašnavih ili staklavih zrna). Utvrđeni sadržaj vode u zrnima u svim frakcijama, bio je manji jer su uzorci određeno vrijeme proveli u laboratoriju prije obrade, što je dovelo i do smanjenja sadržaja vode.

Veći ili manji sadržaj proteina u zrnu, može se pojaviti u zrnima dok su još na klasu u ovisnosti kada je zrno oplođeno, kada je započelo nalijevanje i koliko dugo je trajalo nalijevanje zrna. Dobivene vrijednosti za proteine, ukazuju na jedan trend. Naime, najveći sadržaj proteina utvrđen je u frakcijama 1 i 4, kako u uzorcima koji su uzeti prije mlinske čistionice tako i uzorcima koji su uzeti prije prvog krupljenja. Najmanje proteina utvrđeno je u prosjeku u frakciji $2 \mathrm{u}$ kojoj je utvrđeno i najviše zrna. Iako podaci o sadržaju proteina u zrnu vrlo malo variraju, prije navedeni odnosi su zaista interesantni i za njih postoji objašnjenje.

Tablica 3. Prosječne vrijednosti sadržaja vode u zrnu, sadržaja proteina i sadržaja vlažnog lijepka u frakcijama zrna

Table 3 Average values of moisture content, protein content and wet gluten content in grain fraction

\begin{tabular}{|c|c|c|c|c|c|}
\hline \multirow{2}{*}{ Parametar kakvoće/Quality parameters } & \multicolumn{4}{|c|}{ Frakcija/Fraction } \\
\cline { 3 - 6 } & & $\mathrm{F} 1$ & $\mathrm{~F} 2$ & $\mathrm{~F} 3$ & $\mathrm{~F} 4$ \\
\hline Sadržaj vode u zrnu/ & $\mathrm{pmč}$ & 12,16 & 12,46 & 12,28 & 12,20 \\
\cline { 3 - 6 } Moisture content (\%) & $\mathrm{ppk}$ & 13,16 & 13,20 & 13,44 & 13,54 \\
\hline Sadržaj proteina/ & $\mathrm{pmč}$ & 12,80 & 12,09 & 12,65 & 12,90 \\
\cline { 2 - 6 } Protein content (\%) & $\mathrm{ppk}$ & 12,64 & 12,33 & 12,63 & 12,88 \\
\hline Sadržaj vlažnog lijepka/ & $\mathrm{pmč}$ & 26,74 & 24,05 & 25,09 & 25,60 \\
\cline { 2 - 6 } Wet gluten content (\%) & $\mathrm{ppk}$ & 24,89 & 23,85 & 24,00 & 24,23 \\
\hline
\end{tabular}

pmč - prije mlinske čistionice/before cleaninghouse; ppk - prije prvog krupljenja/before $1^{\text {st }}$ break 
Naime, iako je sadržaj proteina određen uz pomoć NIR uređaja, dokazano je da i kada se sadržaj proteina određuje standardnom metodom (metoda po Kjeldahl-u), manja zrna imaju veći sadržaj proteina na ukupnu masu jer imaju veći udio klice $\mathrm{u}$ odnosu na ostale dijelove zrna, pogotovo u odnosu na endosperm. Do sličnog zaključka došli su i Gwirtz i sur. (1996.), koje citira Miller (2003.), a koji su podijelili zrno nekoliko sorata pšenice u tri frakcije prema veličini (malo, srednje i veliko). Autori su utvrdili da je sadržaj proteina bio najveći u malim zrnima i najmanji u velikim zrnima u slučaju kada je sadržaj proteina bio izražen kao postotak od mase zrna.

Prema podacima iz literature sadržaj proteina i sadržaj vlažnog lijepka nalaze se u pozitivnoj korelaciji. To znači da se povećanjem sadržaja proteina povećava i sadržaj vlažnog lijepka. Iz podataka dobivenih iz ovog istraživanja, može se utvrditi da to baš i nije slučaj. Naime, u frakciji 1 utvrđeno je u prosjeku najviše vlažnog lijepka $(26,74 \%$ i 24,89$)$, ali u istoj frakciji nije u prosjeku utvrđeno i najviše proteina (12,80\% i 12,64\%). Ovo je utvrđeno kako u uzorcima koji su uzeti prije mlinske čistionice tako i u uzorcima koji su uzeti prije prvog krupljenja (tablica 3). Masa 1000 zrna uvelike je pokazatelj i krupnoće zrna. U ovom istraživanju utvrđeno je kako u uzorcima prije mlinske čistionice tako i u uzorcima prije 1. krupljenja, da je veća hektolitarska masa uvijek bila u frakcijama gdje su zrna bila deblja i gdje je masa 1000 zrna bila veća. Do sličnih rezultata došli su Warechowska i sur. (2013.) te Merkle i sur. (1969.) koje citiraju Schuler i sur. (1994.), na osnovi kojih su zaključili da se povećanjem debljine zrna povećavala i hektolitarska masa. U uzorcima prije mlinske čistionice, ali i u uzorcima prije 1. krupljenja, gdje je utvrđena veća hektolitarska masa, nije utvrđen i veći sadržaj proteina. Slabu korelaciju između hektolitarske mase i sadržaja proteina u zrnu, utvrdili su i Ghaderi i sur. (1971.). Za razliku od ovog istraživanja u kojem se nije mogla dovoljno dobro istražiti veza između hektolitarske mase i sadržaja proteina, Schuler i sur. (1995.) utvrdili su pozitivnu korelaciju između hektolitarske mase i sadržaja proteina. Hoseney (1990.), kojeg citiraju Schuler i sur. (1995.), tvrdi da kako zrno postaje više okruglo, kako se puni i kada se pojačava sinteza i ugrađivanje škroba u zrnu tako se generalno smanjuje sadržaj proteina u zrnu.

\section{ZAKLJUČAK}

Prema svemu što je do sada navedeno može se zaključiti da u uzorcima zrna koji su uzeti prije mlinske čistionice ali i u uzorcima koji su uzeti prije prvog krupljenja, frakcije zrna nisu bile jednako zastupljene. Najviše zrna utvrđeno je u frakciji 2 odnosno u frakciji gdje je debljina zrna iznosila od 2,5 do 3,0 mm. 
Na osnovi dobivenih podataka može se zaključiti da je u frakciji 1 utvrđen najmanji sadržaj vode u zrnu, najveći sadržaj vlažnog lijepka i najveća masa 1000 zrna. Navedeno vrijedi kako u uzorcima koji su uzeti prije mlinske čistionice tako i u uzorcima koji su uzeti prije 1. krupljenja. Hektolitarska i masa 1000 zrna smanjuju se sa smanjenjem debljine zrna tj. od frakcije 1 prema frakciji 4 . Statistička analiza varijance pokazala je značajne razlike u hektolitarskoj i masi 1000 zrna između frakcija zrna. Iako u ovom istraživanju nije određen prinos brašna u frakcijama zrna, na osnovi dosadašnjih znanstvenih spoznaja mogu se očekivati bolji rezultati u preradi u frakcijama 1 i 2 u odnosu na frakcije 3 i 4.

\section{LITERATURA}

1. Acar, O., Sanal, T., Köksel, H. (2019.): Effects of wheat kernel size on hardness and various quality characteristics. Quality Assurance and Safety of Crops \& Foods: 0 (0)- Pages: 1 - 6. https://doi.org/10.3920/QAS2019.1552

2. Altaf, Ali, Atkins, I.M. (1969.): Wheat kernel size and dimensions and their relationship to yield, yield components, and test weight and milling yield. Texas Agr. Expt. Sta. Consolidated Progress Rep. 2657-2660.

3. Altaf, Ali, Atkins, I.M., Rooney, L.W., Porter, K.B. (1969.): Kernel dimensions, weight, protein content and milling yield of grain from portions of the wheat spike. Crop Sci. 9:329-330.

4. Boz, H., Gerçekaslan, K.E., Karaoğlu, M.M., Kotancilar, H.G. (2012.): Differences in some physical and chemical properties of wheat grains from different parts within the spike. Turk J Agric For 36 (2012): 309-316.

5. Czarnecki, E., Evans, L.E. (1986.): Effect of weathering during delayed harvest on test weight, seed size, and grain hardness of wheat. Can. J. Plant Sci. 66:473-482.

6. Debbouz, A., Pitz, W. J., Moore, W. R., D'Appolonia, B. L. (1995.): Effect of bleaching on durum wheat and spaghetti quality. Cereal Chemistry, 72, 128-131. https://onlinelibrary.wiley.com/doi/full/10.1002/cche.10311

7. Dziki, D., Laskowski, J. (2005.): Wheat Kernel Physical Properties and Milling Process. Acta Agrophysica, 2005, 6(1), 59-71.

8. Đaković, Lj. (1980.): Pšenično brašno. Tehnološki fakultet Novi Sad.

9. Ghaderi, A., Everson, E.H., Yamazaki, W.T. (1971.): Test weight in relation to the physical and quality characteristics of soft winter wheat. Crop Sci. 11:515-518.

10. Halverson, J., Zeleny, L. (1988.). Criteria of wheat quality. In: Wheat: Chemistry and Technology (edited by Y. Pomeranz). Vol. 1. pp. 15-45.USA, St. Paul, Minnesota; American Association of Cereal Chemists Inc. 
11. Jelača, S. (1972.): Hemija i tehnologija pšenice. JIPI, Zavod za tehnologiju žita i brašna, Novi Sad.

12. Kljusurić, S. (2000.): Uvod u tehnologiju mljevenja pšenice, Metković, 2000.

13. Krička, T., Pliestić, S., Dobričević, N., Fazlić, S. (1997.): Analiza primjesa pšenice (Triticum aestivum spp. Vulgare) prije dorade. Zbornik radova, Prvi Hrvatski kongres tehnologa prerade žitarica, BRAŠNO - KRUH, Opatija, 1997.

14. Miller, C.L. (2003.). Variation in single kernel hardness within the wheat spike. A THESIS, MASTER OF SCIENCE, Department of Grain Science and Industry College of Agriculture KANSAS STATE UNIVERSITY Manhattan, Kansas 2008. citeseerx.ist.psu.edu/viewdoc/download?doi=10.1.1.533.990

15. Ponce-García, N., Ramírez-Wong, B., Escalante-Aburto, A., Torres-Chávez, P.I., Serna-Saldivar, S.O. (2017.): Grading Factors of Wheat Kernels Based on Their Physical Properties. In book: Wheat Improvement, Management and Utilization, Chapter: 13. Publisher: Intech.

16. Posner, E.S., Hibbs, A. N. (1997.): Theory of tempering wheat for milling. Pages 110-114 in: Wheat Flour Milling. E. S. Posner and A. N. Hibbs, eds. AACC International: St Paul, MN.

17. Posner, E.S. (2000.): Wheat, in Handbook of Cereal Science and Technology, $2^{\text {nd }}$ ed. (Kulp, K., and Ponte, J.G., eds.) Marcel Dekker, Inc., New York, Basel, str. 1-29. (2000).

18. Pospišil, A. (2010.): Ratarstvo. Zrinski, Čakovec. 2010.

19. Protić, R., Mirić, M., Protić, N., Jovanović, Ž., Jovin, P. (2007.): The test weight of several winter wheat genotypes under various sowing dates and nitrogen fertilizer rates. Romanian Agricultural Research, No, 24/2007, pp 43-46.

20. Schuler, F.S., Bacon, R.K., Gbur, E.E. (1994.): Kernel and spike character influence on test weight of soft red winter wheat. Crop Sci. 34:1309-1313.

21. Schuler, S.F., Bacon, R.K., Finney, P.L., Gbur, E.E. (1995.): Relationship of Test Weight and Kernel Properties to Milling and Baking Quality in Soft Red Winter Wheat. Crop Sci. 35(4), 949-953.

22. Službeni list $74 / 88$, Pravilnik o metodama uzimanja uzoraka i metodama fizikalnih i kemijskih analiza za kontrolu kvalitete žita, mlinskih i pekarskih proizvoda, tjestenina i brzo smrznutih tijesta.

23. Ujević, A. (1988.): Tehnologija dorade i čuvanje sjemena. Fakultet poljoprivrednih znanosti Sveučilišta u Zagrebu, OOUR Institut za oplemenjivanje i proizvodnju bilja Zagreb, Marulićev trg 5, Zrinski Čakovec. 1988.

24. Varga, B., Svečnjak, Z., Pospišil, A., Vinter, J. (2000.): Promjene nekih agronomskih svojstava sorata ozime pšenice u ovisnosti o razini agrotehnike. Poljoprivredna znanstvena smotra, 65(1):37-44, 2000. 
25. Varga, B., Svečnjak, Z., Jurković, Z., Kovačević, J., Jukić, Ž. (2003.): Wheat Grain and Flour Quality as Affected by Cropping Intensity. Food. Technol. Biotechnol. 41 (4) 321-329 (2003).

26. Vešnik, F., Dobričević, J., Kerep, N. (1989.): Utjecaj povećane vlažnosti pšenice na izmjere apsolutne i hektolitarske mase i količinu primjesa. Zbornik radova, V. Savjetovanje tehnologa sušenja i skladištenja, Toplice Topusko, 169-176.

27. Warechowska, M., Warechowski, J., Markowska, A. (2013.): Interrelations between selected physical and technological properties of wheat grain. Technical Sciences 16(4):281-290, 2013. http://www.uwm.edu.pl/wnt/technicalsc/tech_16_4/warechowski.pdf

28. Yamazaki, W.T., Brigle, L.W. (1969.): Components of test weight in soft wheat. Crop Sci. 9: 457-459.

29. Yoon, B.S., Brorsen, B.W., Lyford, C.P. (2002.): Value of Increasing Kernel Uniformity. Journal of Agricultural and Resource Econimics. 27(2). Pp. 481-494.

30. <http://www.agionica.hr $>$. Pristupljeno 12. lipnja 2012.

31. <http://www.noackgroup.com>. Pristupljeno 10. lipnja 2012.

Adresa autora-Author's address:

Prof. dr. sc. Željko Jukić; e-mail: zjukic@agr.hr

Prof. dr. sc. Ana Pospišil

Sveučilište u Zagrebu, Agronomski fakultet,

Zavod za specijalnu proizvodnju bilja,

Svetošimunska cesta 25, 10000 Zagreb

Prof. dr. sc. Tajana Krička

Sveučilište u Zagrebu, Agronomski fakultet,

Zavod za poljoprivrednu tehnologiju, skladištenje i transport,

Svetošimunska cesta 25, 10000 Zagreb

Tihomir Radiček, mag.ing.agr., student

Karmen Jukić, dipl.ing.

BELJE plus d.o.o. PC TSH PJ Mlin Križevci,

Bjelovarska 1048260 Križevci
Primljeno - Received

28.03.2020. 
